\title{
ANALYSIS OF THE SURFACE PROFILE AND ITS MATERIAL SHARE DURING THE GRINDING INCONEL 718 ALLOY
}

\section{Martin Novák', Nataša Náprstková1, Jerzy Józwik²}

1 Faculty of Production Technology and Management, Jan Evangelista Purkyně University in Ústí nad Labem, Pasteurova 1, 40096 Ústí nad Labem, Czech Republic, e-mail: novak@fvtm.ujep.cz; naprstkova@fvtm.ujep.cz

2 Faculty of Mechanical Engineering, Lublin University of Technology, 36 Nadbystrzycka Str., 20-618 Lublin, Poland, e-mail: j.jozwik@pollub.pl

Received: 2015.04.10

Accepted: 2015.05 .08

Published: 2015.06.01

\begin{abstract}
Grinding is still an important method for surface finishing. At FPTM JEPU research, which deals with this issue is conducted. Experiments are carried out with grinding various materials under different conditions and then selected components of the surface integrity are evaluated. They include roughness $R a, R m$ and $R z$, Material ratio curve (Abbott Firestone curve) and also the obtained roundness. This article deals with grinding nickel Inconel 718 alloy, when selected cutting grinding conditions were used and subsequently the surface profile and the material ratio curve were measured and evaluated.
\end{abstract}

Keywords: grinding, Abbott Firestone curve, Inconel.

\section{INTRODUCTION}

The importance of processing nickel alloys has been currently increasing, particularly due to their good properties, such as high $R m$ and their use for relatively high temperatures. The experiment deals with grinding a specific nickel alloy marked as Inconel 718 (NiCr1NbMo).

It is a super-alloy having a high content of nickel and it is used at extreme temperatures and in strongly oxidizing environments. This alloy was originally developed for the construction of space shuttles, but today it is also used in civilian and military sphere, for example in the aerospace industry, where it is used in the manufacture of jet engines, in the automotive industry for exhaust systems, valves, etc., in the chemical industry for pipes producing, heat exchangers, etc. This material is difficult to machine with interesting properties, which has a great potential for the future, which is why it was chosen for this experiment $[1,2]$.

Inconel is a family of austenite nickel-chromium-based superalloys. Table 1 presents a chemical compound of this alloy, according to the materials producer [3].

One of the parameters used to describe the surface roughness and profile is called Material ratio curve (Abbott Firestone curve). This curve

Table 1. Limiting Chemical composition of Inconel 718 [3]

\begin{tabular}{|c|c|c|c|c|}
\hline \multicolumn{5}{|c|}{ INCONEL 718} \\
\hline \multicolumn{5}{|c|}{ Element ( $\%$ by mass) } \\
\hline $\mathrm{C}$ & Si & $\mathrm{Mn}$ & $P$ & $S$ \\
\hline $0.08 \max$ & $0.35 \max$ & $0.35 \max$ & $0.015 \max$ & $0.015 \max$ \\
\hline $\mathrm{Cr}$ & Mo & $\mathrm{Ni}$ & $\mathrm{Al}$ & $B$ \\
\hline $17.0-21.0$ & $2.8-3.3$ & $50.0-55.0$ & $0.2-0.8$ & $0.006 \max$ \\
\hline Co & $\mathrm{Cu}$ & $\mathrm{Ti}$ & $\mathrm{Fe}$ & $\mathrm{Nb}+\mathrm{Ta}$ \\
\hline $1.0 \max$ & $0.3 \max$ & $0.65-1.15$ & balance & $4.75-5.50$ \\
\hline
\end{tabular}


shows the relationship between the depressions (places without material) and protrusions (places with the material). Whether they are depressions or protrusions it will be determined by the fact if the inequalities take positive or negative values from the profile core. For each finishing technology, Abbott Firestone curve is characteristic and it has particular relevance for assessing loaded functional surfaces, solving problems of friction, wear and lubrication. The value of upper part profile $R p k$ is the profile part which wears rapidly, for example it is used for assessing the nature and speed of the running-in sliding or rolling bearings. The lower part $R v k$ is again important for lubrication of the contact surfaces $[4,5,6,7]$.

The paper describes experiments and their results, which were conducted at FPTM JEPU with grinding Inconel 718.

\section{EXPERIMENT}

As mentioned above, the experiments were carried out for the material designated as INCONEL 718 (NiCr19NbMo). It is a hardenable alloy based on Ni-Cr containing a large quantity of iron, niobium, molybdenum, together with minor amounts of aluminum and titanium. It combines the corrosion resistance and high creep rupture strength to $700{ }^{\circ} \mathrm{C}$ with excellent weldability, including resistance to cracking. It is used in the aerospace industry, for gas turbines, in rocket engines, in the extraction of oil and gas and in the nuclear industry. In the experiment the alloy was subjected to spectral analysis, for verifying the expected chemical composition (Table 2) which was confirmed (see Table 1) [1, 3].
For the realization of the experiment a grinding wheel with grinding material $\mathrm{SiC}$ (silicon carbide) was chosen. As a material of this abrasive wheel green silicon carbide is applied. For the experiment semisynthetic process liquid was used. It was a $5 \%$ aqueous solution.

Grinding of all samples was carried out on a cylindrical grinder BU-16. The total of 12 samples were grounded and measured. Then a combination of cutting conditions were selected (see Table 3 and 4). The experiment utilized two methods of grinding, longitudinal and grooving $[1,2]$.

\section{MEASUREMENTS AND ANALYSIS}

As already mentioned above, profile and material ratio of the surface was evaluated on the machined surfaces, which are some of the parameters for the assessment of the surface quality after machining. The measurements of surface profile and material ratio were carried out on a device Hommel Tester T1000 according to DIN EN ISO 4287.

As mentioned above, the surface profile provides information on the segmentation of the surface, which is caused by many factors acting during machining, e.g. selected cutting conditions, trembling, rigidity of system, edge wear etc. Material ratio curve provides us with information about the structure of surface profile, therefore, the ratio of the core profile for dips and protrusions. The curve course can be used to evaluate the expected behavior of the component (running in the drive shaft, wear the loading area etc.). If the curve is decreasing slowly, it is a solid profile with a small volume of wells, and therefore, the surface is with very

Table 2. The chemical composition of the sample from Inconel 718 alloy according to the spectral analysis

\begin{tabular}{|c|c|c|c|c|}
\hline \multicolumn{5}{|c|}{ INCONEL 718} \\
\hline \multicolumn{5}{|c|}{ Element ( $\%$ by mass) } \\
\hline $\mathrm{C}$ & $\mathrm{Si}$ & $\mathrm{Mn}$ & $\mathrm{P}$ & $S$ \\
\hline 0.015 & 0.01 & 0.06 & 0.002 & 0.0002 \\
\hline $\mathrm{Cr}$ & Mo & $\mathrm{Ni}$ & $\mathrm{Al}$ & B \\
\hline 17.96 & 2.99 & 53.55 & 0.53 & 0.002 \\
\hline Co & $\mathrm{Cu}$ & $\mathrm{Pb}$ & $\mathrm{Sn}$ & $\mathrm{Ti}$ \\
\hline 0.06 & $<0.1$ & 0.0001 & 0.0009 & 0.98 \\
\hline $\mathrm{Bi}$ & $\mathrm{Ca}$ & $\mathrm{Mg}$ & $\mathrm{Se}$ & $\mathrm{Fe}$ \\
\hline$<0.00003$ & 0.0005 & 0.0006 & 0.0001 & rest \\
\hline \multicolumn{5}{|l|}{$\mathrm{Nb}+\mathrm{Ta}$} \\
\hline 4.965 & & & & \\
\hline
\end{tabular}


Table 3. Cutting conditions for longitudinal grinding

\begin{tabular}{|c|c|c|c|}
\hline \multicolumn{4}{|c|}{ Longitudinal grinding, wheel SiC } \\
\hline Sample No. & Cutting speed $v_{c}\left[\mathrm{~m} \cdot \mathrm{s}^{-1}\right]$ & Feed $f\left[\mathrm{~m} \cdot \min ^{-1}\right]$ & Workpiece speed $v_{w}\left[\mathrm{~m} \cdot \mathrm{min}^{-1}\right]$ \\
\hline 1 & \multirow{2}{*}{35} & 0.02 & \multirow{6}{*}{15} \\
\hline 2 & & 0.04 & \\
\hline 3 & \multirow{2}{*}{40} & 0.02 & \\
\hline 4 & & 0.04 & \\
\hline 5 & \multirow{2}{*}{45} & 0.02 & \\
\hline 6 & & 0.04 & \\
\hline
\end{tabular}

Table 4. Cutting conditions for grooving grinding

\begin{tabular}{|c|c|c|c|}
\hline \multicolumn{4}{|c|}{ Grooving grinding, wheel SiC } \\
\hline Sample No. & Cutting speed $v_{c}\left[\mathrm{~m} \cdot \mathrm{s}^{-1}\right]$ & Infeed $v_{f}\left[\mathrm{~mm} \cdot \mathrm{min}^{-1}\right]$ & Workpiece speed $v_{w}\left[\mathrm{~m} \cdot \mathrm{min}^{-1}\right]$ \\
\hline 7 & \multirow{3}{*}{35} & 0.13 & \multirow{6}{*}{15} \\
\hline 8 & & 0.17 & \\
\hline 9 & & 0.26 & \\
\hline 10 & \multirow{3}{*}{40} & 0.13 & \\
\hline 11 & & 0.17 & \\
\hline 12 & & 0.26 & \\
\hline
\end{tabular}

good antiwear properties. Steeply declining curve by contrast, notes strong cracks surface and thus the unfavorable surface properties and poor prognosis. $[4,5,9,11]$

The first surfaces were obtained by the longitudinal grinding. Figures 1 to 6 present the profiles of samples from 1 to 6 ground according to the cutting conditions (see Table 3 ).

The largest waviness is showed in sample 1. Also, sample 5 shows in comparison with other samples worse quality, dips and protrusions are not so crowded as in sample 1 but in turn, they are considerably deeper. In comparison with all samples machined by longitudinal grinding, the best quality is showed in sample $2(v=$ $\left.35 \mathrm{~m} \cdot \mathrm{s}^{-1}, f=0.04 \mathrm{~m} \cdot \mathrm{min}^{-1}\right)$ and $6\left(v_{c}=45 \mathrm{~m} \cdot \mathrm{s}^{-1}\right.$, $\left.f=0.04 \mathrm{~m} \cdot \mathrm{min}^{-1}\right)$.

If we look then at material ratio of individual samples (Fig. 7-12) the above mentioned facts are to some extent observable here too. Here, however, the worst material ratio curve is showed in sample $5\left(v_{c}=45 \mathrm{~m} \cdot \mathrm{s}^{-1}, f=0.02 \mathrm{~m} \cdot \mathrm{min}^{-1}\right)$, although waviness was worst for sample 1 , so its material ratio curve belongs to those advantageous (this is due to the amount and ratio of dips and protrusions). In comparison with all samples machined by longitudinal grinding, advantageous material ratio curve is showed in sample $3\left(v_{c}=\right.$ $\left.40 \mathrm{~m} \cdot \mathrm{s}^{-1}, f=0.02 \mathrm{~m} \cdot \mathrm{min}^{-1}\right)$ and sample 6 again $\left(v_{c}\right.$ $\left.=45 \mathrm{~m} \cdot \mathrm{s}^{-1}, f=0.04 \mathrm{~m} \cdot \mathrm{min}^{-1}\right)$.

Furthermore, the evaluated surfaces were obtained by grooving grinding, as mentioned above, there were used two cutting speeds $v_{c}$ for three infeeds $v_{f}$. Generally, it can be stated that both, profiles and material ratio curves had worst values in comparison with the longitudinal grinding, as shown in Figures 13 to 24. Within grooving grinding sample 8 fared preferably

R- Profil Filtr M1 DIN4777 Lc $=0.800 \mathrm{~mm}$

0.0

$[\mu \mathrm{m}]$

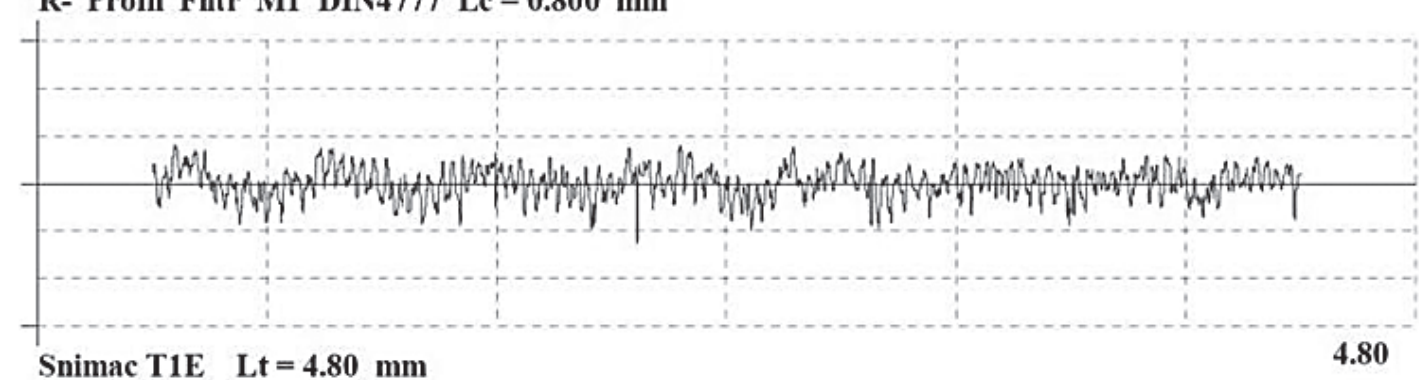

Fig. 1. Surface profile, longitudinal grinding, $v_{c}=35 \mathrm{~m} \cdot \mathrm{s}^{-1}, f=0.02 \mathrm{~m} \cdot \mathrm{min}^{-1}$, sample 1 
R- Profil Filtr M1 DIN4777 Lc $=0.800 \mathrm{~mm}$

2.5
0.0
$[\mu \mathrm{m}]$
-2.5

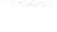

Snimac T1E Lt $=4.80 \mathrm{~mm}$

Fig. 2. Surface profile, longitudinal grinding, $v_{c}=35 \mathrm{~m} \cdot \mathrm{s}^{-1}, f=0.04 \mathrm{~m} \cdot \mathrm{min}^{-1}$, sample 2

\section{R- Profil Filtr M1 DIN4777 Lc $=0.800 \mathrm{~mm}$}

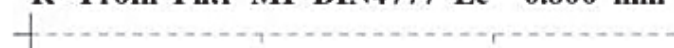

2.5
0.0

$[\mu \mathrm{m}]$
-2.5

Snimac T1E $\quad \mathrm{Lt}=4.80 \mathrm{~mm}$

Fig. 3. Surface profile, longitudinal grinding, $v_{c}=40 \mathrm{~m} \cdot \mathrm{s}^{-1}, f=0.02 \mathrm{~m} \cdot \mathrm{min}^{-1}$, sample 3

R- Profil Filtr M1 DIN4777 Lc $=0.800 \mathrm{~mm}$

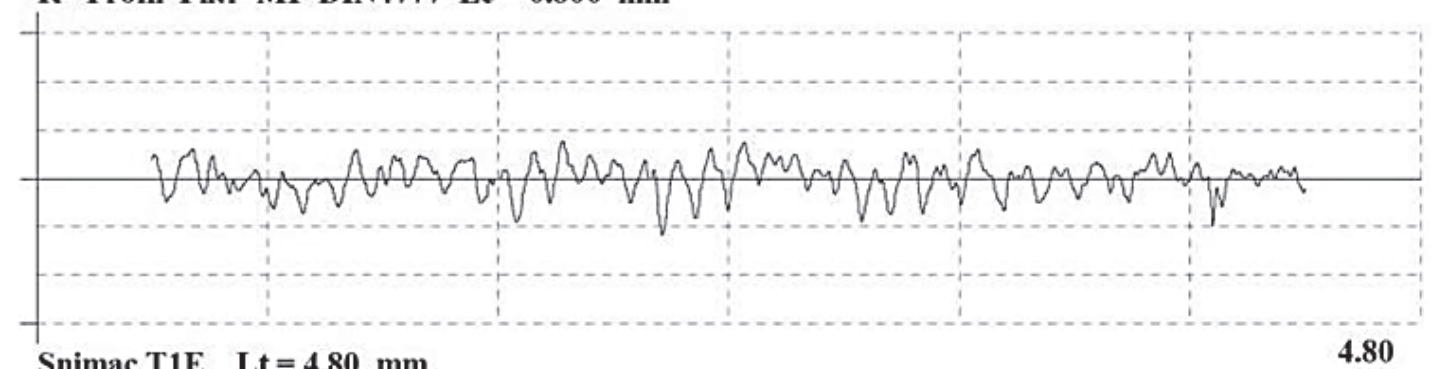

Snimac T1E Lt $=4.80 \mathrm{~mm}$

Fig. 4. Surface profile, longitudinal grinding, $v_{c}=40 \mathrm{~m} \cdot \mathrm{s}^{-1}, f=0.04 \mathrm{~m} \cdot \mathrm{min}^{-1}$, sample 4

2.5
0.0

$[\mu \mathrm{m}]$
-2.5

R- Profil Filtr M1 DIN4777 Lc $=0.800 \mathrm{~mm}$

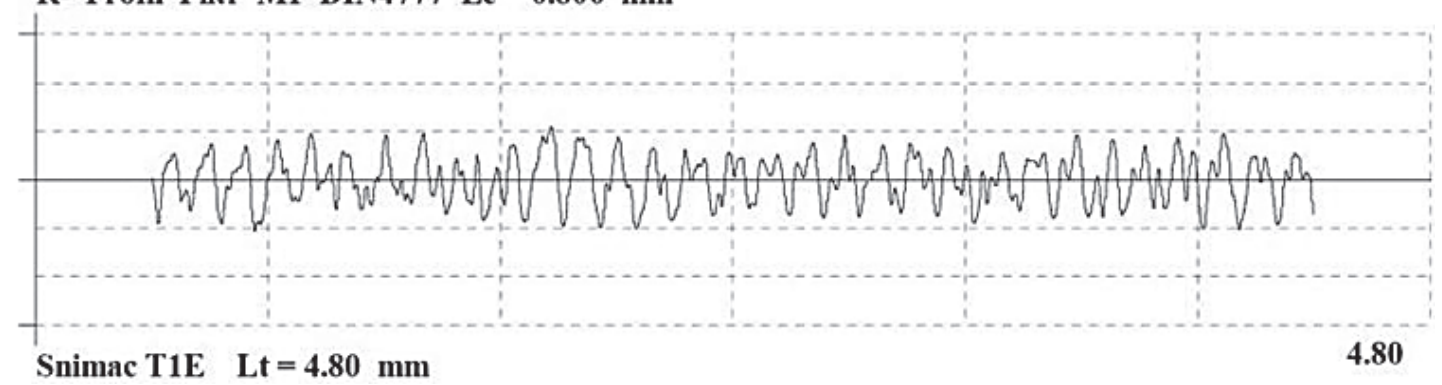

Fig. 5. Surface profile, longitudinal grinding, $v_{c}=45 \mathrm{~m} \cdot \mathrm{s}^{-1}, f=0.02 \mathrm{~m} \cdot \mathrm{min}^{-1}$, sample 5

2.5

0.0

$[\mu \mathrm{m}]$

$-2.5$

R- Profil Filtr M1 DIN4777 Lc $=0.800 \mathrm{~mm}$

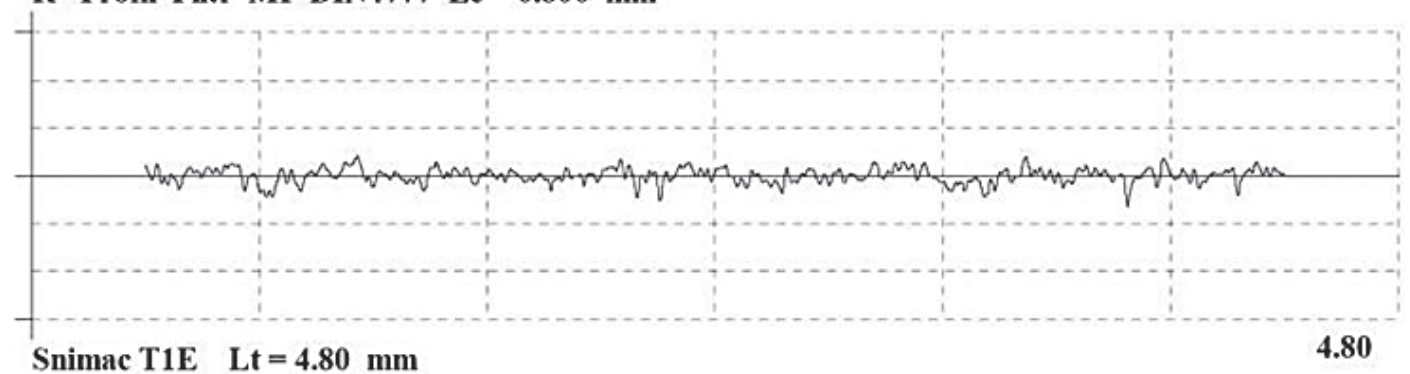

Fig. 6. Surface profile, longitudinal grinding, $v_{c}=45 \mathrm{~m} \cdot \mathrm{s}^{-1}, f=0.04 \mathrm{~m} \cdot \mathrm{min}^{-1}$, sample 6 


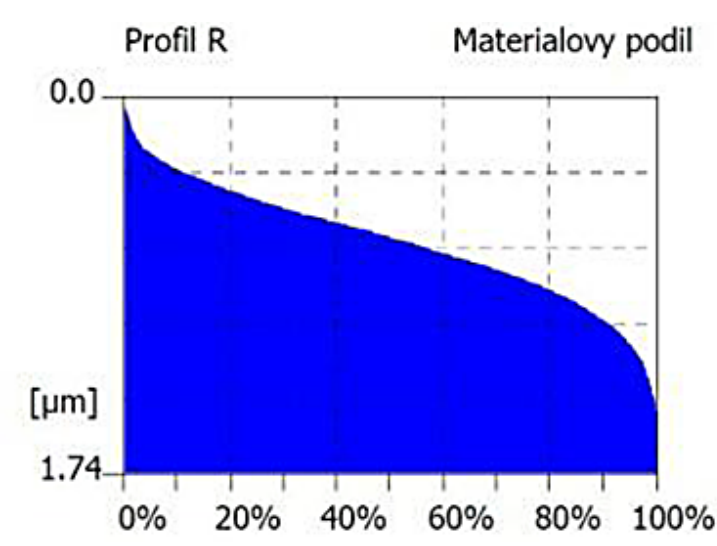

Fig. 7. Material ratio curve, longitudinal grinding, $v_{c}=35 \mathrm{~m} \cdot \mathrm{s}^{-1}, f=0.02 \mathrm{~m} \cdot \mathrm{min}^{-1}$, sample 1

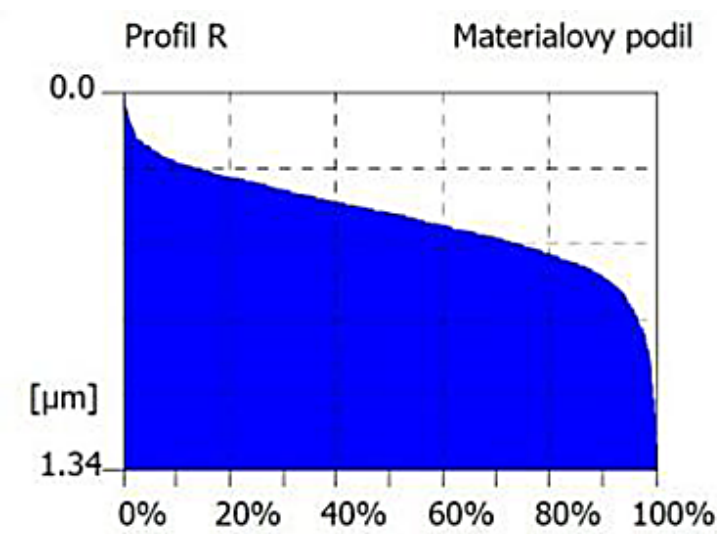

Fig. 9. Material ratio curve, longitudinal grinding, $v_{c}=40 \mathrm{~m} \cdot \mathrm{s}^{-1}, \mathrm{f}=0.02 \mathrm{~m} \cdot \mathrm{min}^{-1}$, sample 3

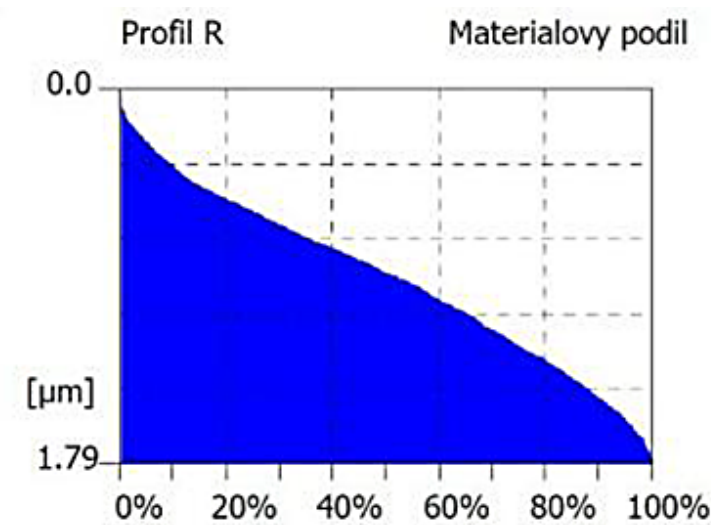

Fig. 11. Material ratio curve, longitudinal grinding, $v_{c}=45 \mathrm{~m} \cdot \mathrm{s}^{-1}, f=0.02 \mathrm{~m} \cdot \mathrm{min}^{-1}$, sample 5

$\left(v_{c}=35 \mathrm{~m} \cdot \mathrm{s}^{-1}\right.$ and $\left.v_{f}=0.17 \mathrm{~mm} \cdot \mathrm{min}^{-1}\right)$ in terms of the profile curve and in terms of the material ratio curve it is sample $9\left(v_{c}=35 \mathrm{~m} \cdot \mathrm{s}^{-1}\right.$ and $\left.v_{f}=0.26 \mathrm{~mm} \cdot \mathrm{min}^{-1}\right)$. The worst results in the context of the material ratio curve are showed in sample $11\left(v_{c}=40 \mathrm{~m} \cdot \mathrm{s}^{-1}\right.$ and $\left.v_{f}=0.17 \mathrm{~mm} \cdot \mathrm{min}^{-1}\right)$.

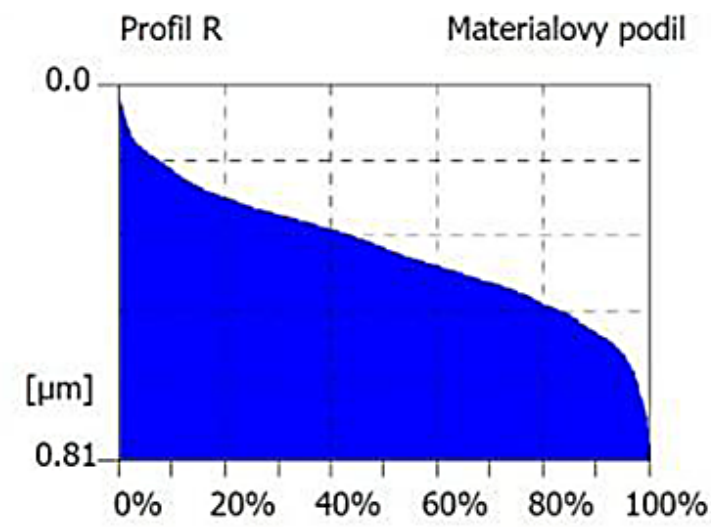

Fig. 8. Material ratio curve, longitudinal grinding, $v_{c}=35 \mathrm{~m} \cdot \mathrm{s}^{-1}, f=0.04 \mathrm{~m} \cdot \mathrm{min}^{-1}$, sample 2

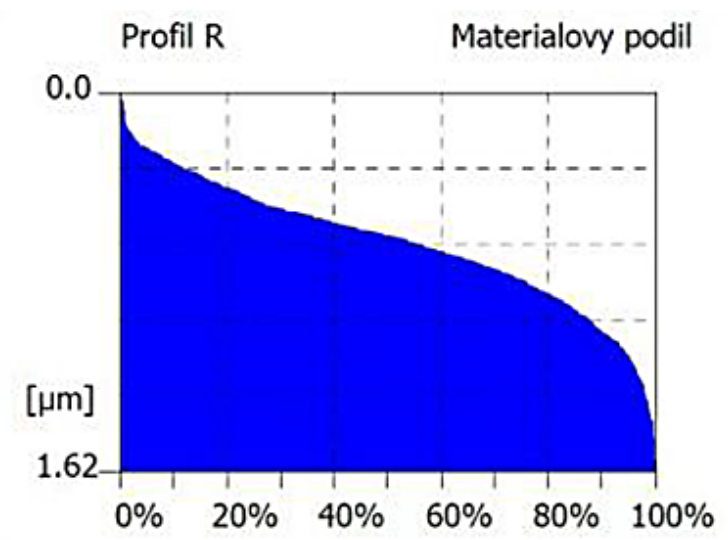

Fig. 10. Material ratio curve, longitudinal grinding, $\mathrm{v}_{\mathrm{c}}=40 \mathrm{~m} \cdot \mathrm{s}^{-1}, \mathrm{f}=0.04 \mathrm{~m} \cdot \mathrm{min}^{-1}$, sample 4

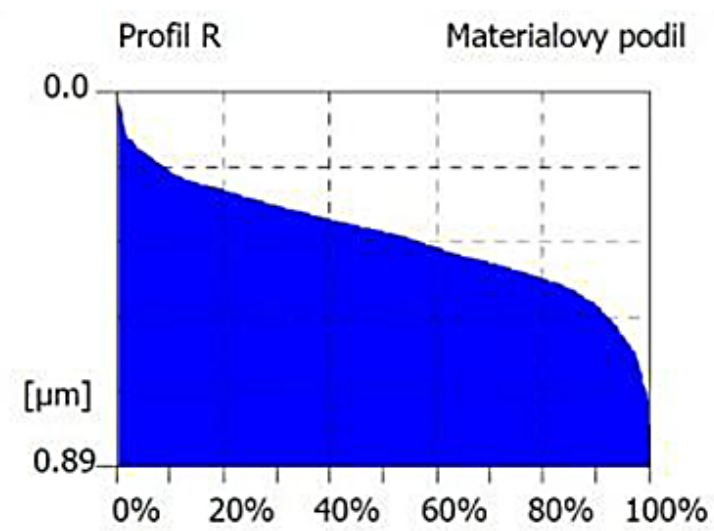

Fig. 12. Material ratio curve, longitudinal grinding, $v_{c}=45 \mathrm{~m} \cdot \mathrm{s}^{-1}, f=0.04 \mathrm{~m} \cdot \mathrm{min}^{-1}$, sample 6

\section{CONCLUSION}

Machining of nickel alloys is currently a popular technology due to the expansion of nickel alloys use in the industry, and because they are difficult to machine materials, due to their hardness, this subject is necessary to pay attention to. At FPTM 
R- Profil vyrovnan Filtr ISO 11562(M1) Lc $=0.800 \mathrm{~mm}$

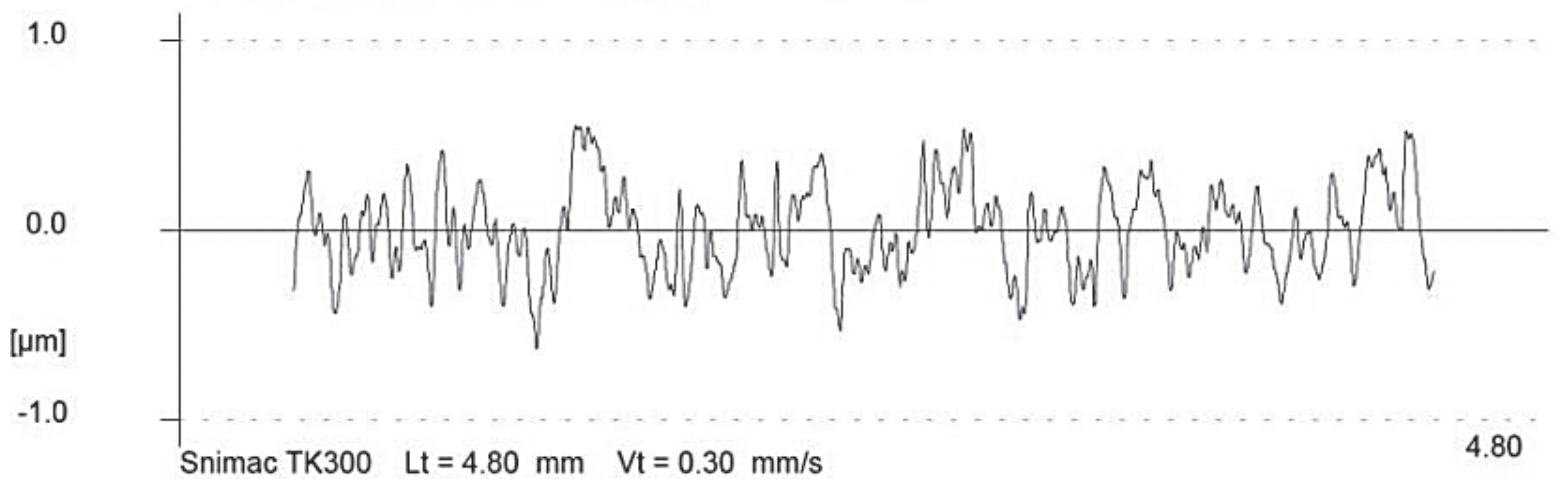

Fig. 13. Surface profile, grooving grinding, $v_{c}=35 \mathrm{~m} \cdot \mathrm{s}^{-1}, v_{f}=0.13 \mathrm{~mm} \cdot \mathrm{min}^{-1}$, sample 7

R- Profil vyrovnan Filtr ISO 11562(M1) LC $=0.800 \mathrm{~mm}$

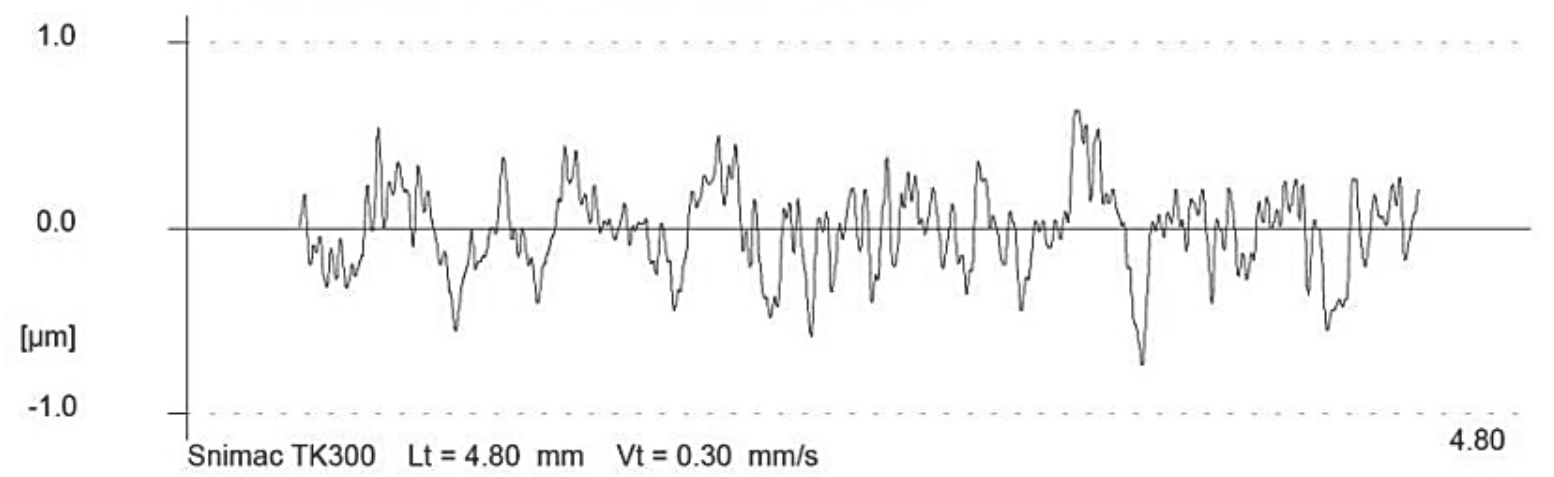

Fig. 14. Surface profile, grooving grinding, $v_{c}=35 \mathrm{~m} \cdot \mathrm{s}^{-1}, v_{f}=0.17 \mathrm{~mm} \cdot \mathrm{min}^{-1}$, sample 8

R- Profil vyrovnan Filtr ISO 11562(M1) LC $=0.800 \mathrm{~mm}$

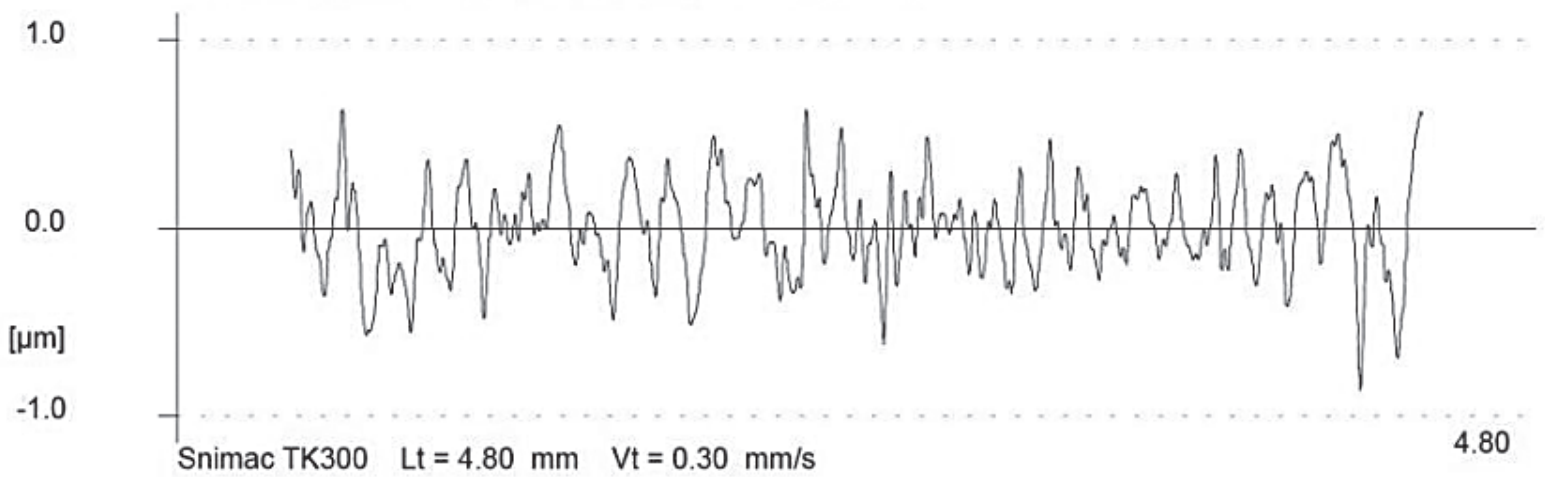

Fig. 15. Surface profile, grooving grinding, $v_{c}=35 \mathrm{~m} \cdot \mathrm{s}^{-1}, v_{f}=0.26 \mathrm{~mm} \cdot \mathrm{min}^{-1}$, sample 9

R- Profil vyrovnan Filtr ISO 11562(M1) Lc $=0.800 \mathrm{~mm}$

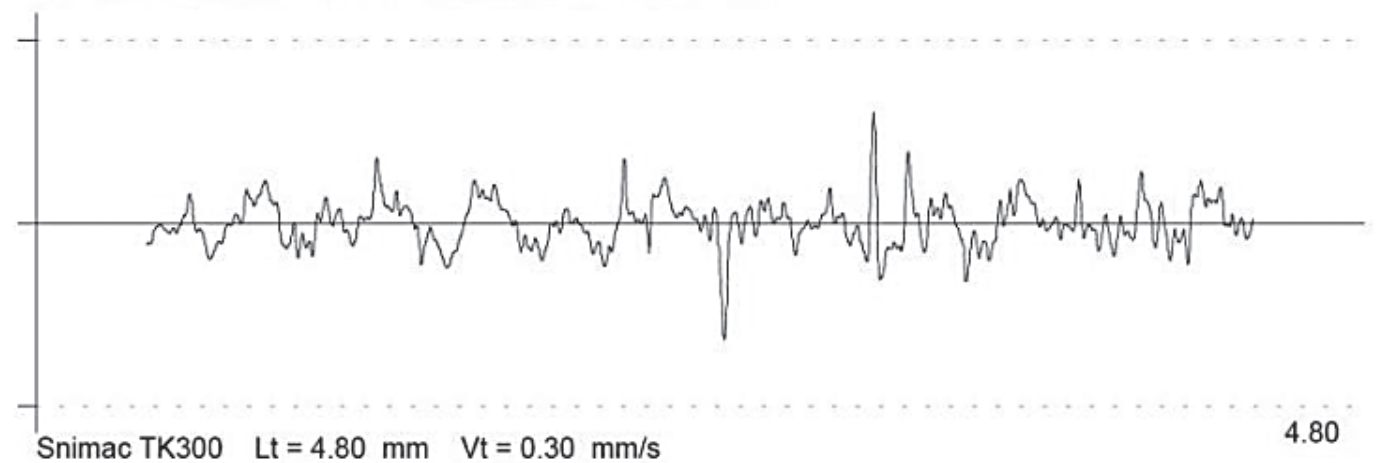

Fig. 16. Surface profile, grooving grinding, $v_{c}=40 \mathrm{~m} \cdot \mathrm{s}^{-1}, v_{f}=0.13 \mathrm{~mm} \cdot \mathrm{min}^{-1}$, sample 10 
R- Profil vyrovnan Filtr ISO 11562(M1) Lc $=0.800 \mathrm{~mm}$

2.5

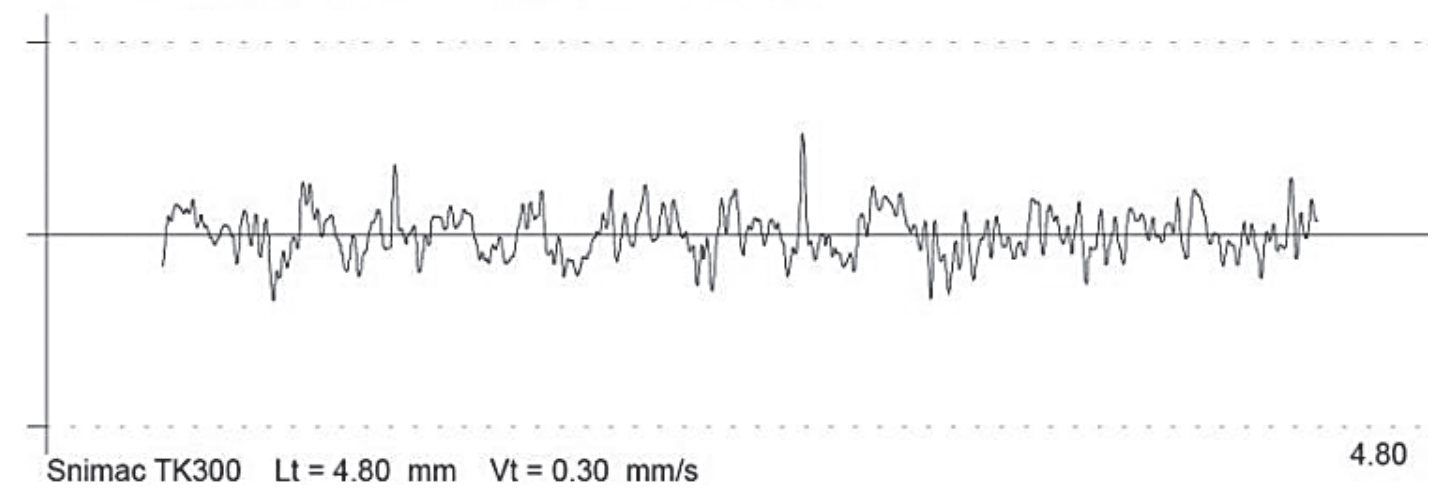

Fig. 17. Surface profile, grooving grinding, $v_{c}=40 \mathrm{~m} \cdot \mathrm{s}^{-1}, v_{f}=0.17 \mathrm{~mm} \cdot \mathrm{min}^{-1}$, sample 11

R- Profil vyrovnan Filtr ISO 11562(M1) Lc $=0.800 \mathrm{~mm}$

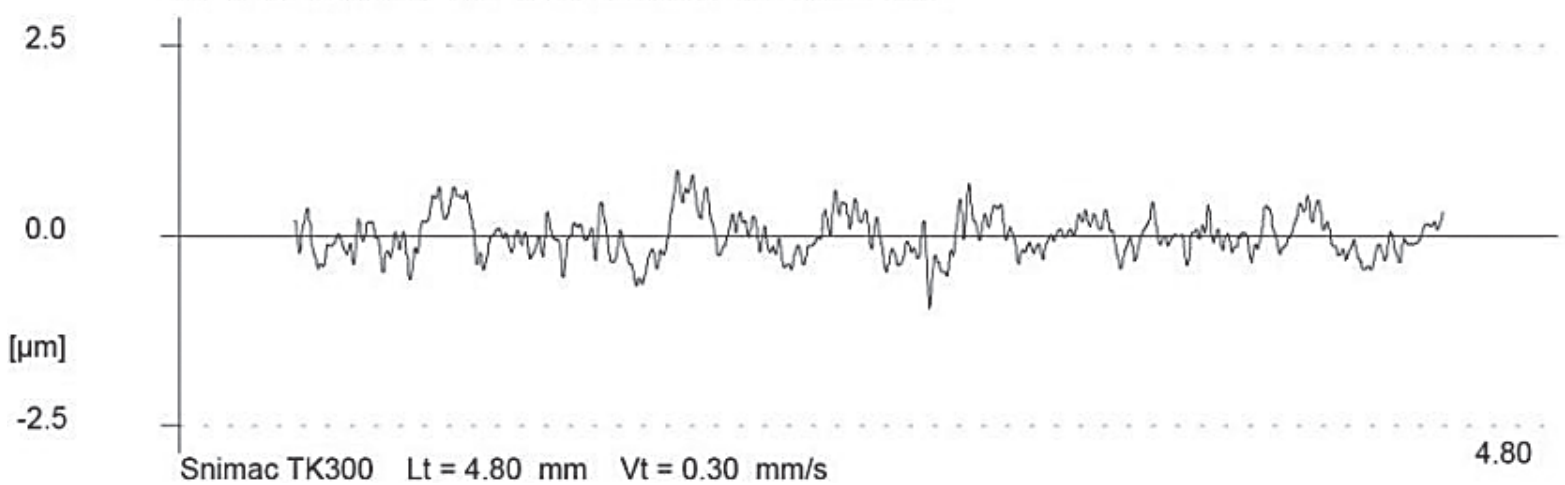

Fig. 18. Surface profile, grooving grinding, $v_{c}=40 \mathrm{~m} \cdot \mathrm{s}^{-1}, v_{f}=0.26 \mathrm{~mm} \cdot \mathrm{min}^{-1}$, sample 12

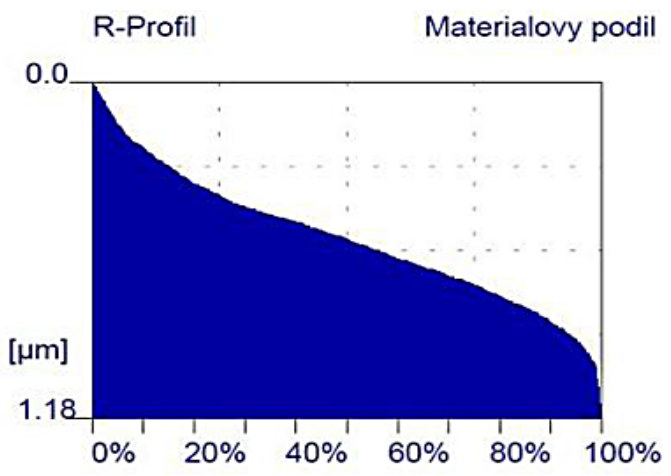

Fig. 19. Material ratio curve, grooving grinding, $v_{c}=$ $35 \mathrm{~m} \cdot \mathrm{s}^{-1}, v_{f}=0.13 \mathrm{~mm} \cdot \mathrm{min}^{-1}$, sample 7

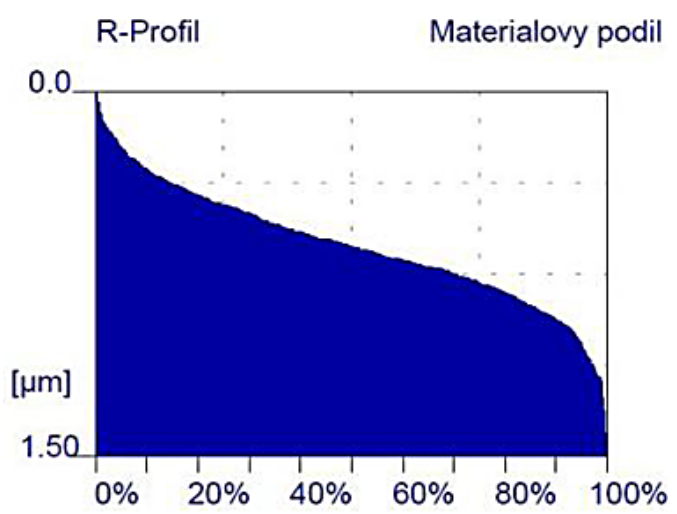

Fig. 21. Material ratio curve, grooving grinding, $v_{c}=35 \mathrm{~m} \cdot \mathrm{s}^{-1}, v_{f}=0.26 \mathrm{~mm} \cdot \mathrm{min}^{-1}$, sample 9

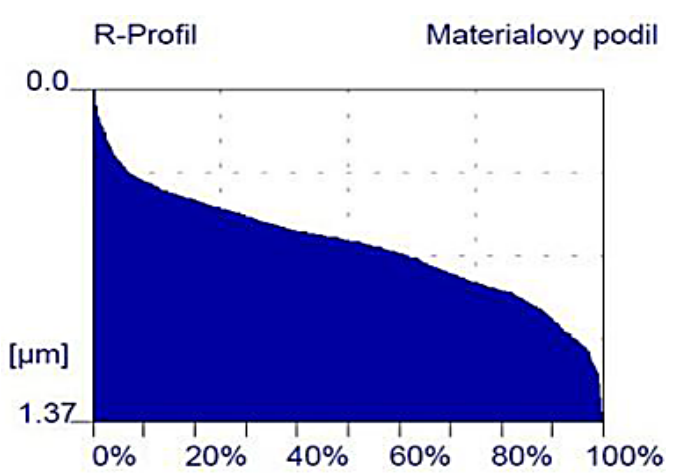

Fig. 20. Material ratio curve, grooving grinding, $v_{c}=35 \mathrm{~m} \cdot \mathrm{s}^{-1}, v_{f}=0.17 \mathrm{~mm} \cdot \mathrm{min}^{-1}$, sample 8

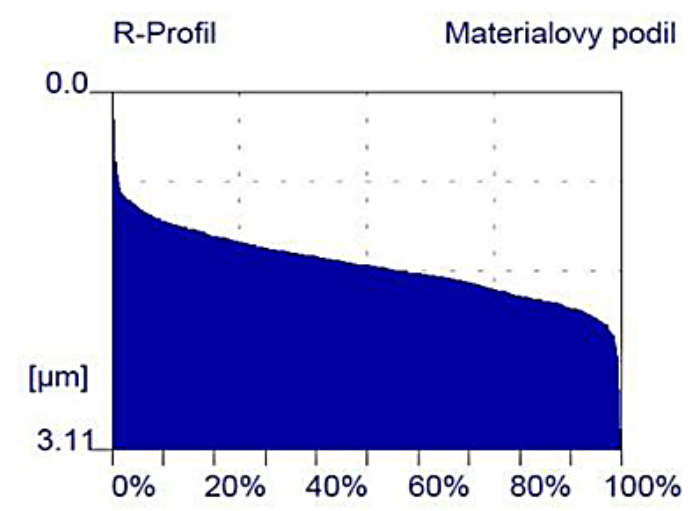

Fig. 22. Material ratio curve, grooving grinding, $v_{c}=40 \mathrm{~m} \cdot \mathrm{s}^{-1}, v_{f}=0.13 \mathrm{~mm} \cdot \mathrm{min}^{-1}$, sample 10 


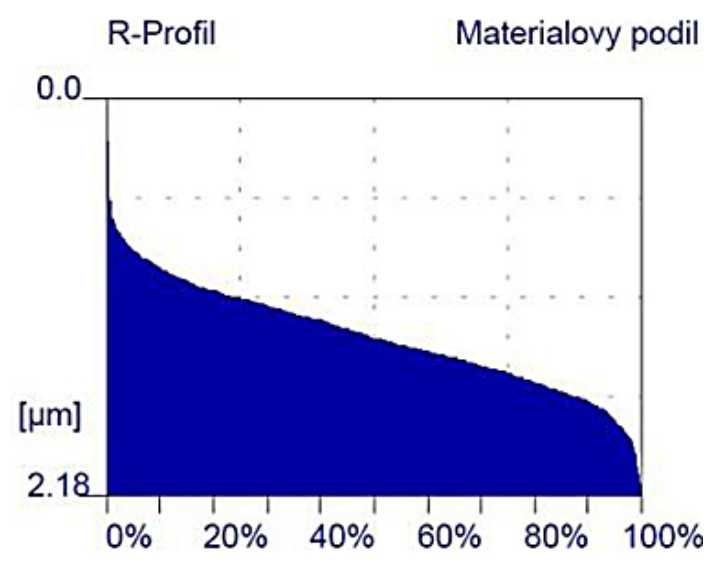

Fig. 23. Material ratio curve, grooving grinding, $v_{c}=40 \mathrm{~m} \cdot \mathrm{s}^{-1}, v_{f}=0.17 \mathrm{~mm} \cdot \mathrm{min}^{-1}$, sample 11

JEPU there are experiments carried out in this area and one of their components introduces this contribution. Experiments were carried out with grinding specific Inconel 718 alloy. The samples were ground longitudinally and by grooving grinding.

Generally, practically all samples appeared ground by longitudinal grinding and preferably for grinding conditions $v_{c}=45 \mathrm{~m} \cdot \mathrm{s}^{-1}, \mathrm{f}=0.04$ $\mathrm{m} \cdot \mathrm{min}^{-1}$ (sample 6) were better for all cutting conditions because the profile has a relatively flat pits and protrusions, nor on the profile was any waviness visible. Furthermore, the material ration curve decreases relatively slowly in this sample, which again means a solid profile with a small volume of pits and protrusions. It is therefore stated in the experiment that in the context of performed measurements the best profile and the material ratio curve was acquired for cutting conditions for longitudinal grinding with cutting conditions $v_{c}=45 \mathrm{~m} \cdot \mathrm{s}^{-1}, f=0.04 \mathrm{~m} \cdot \mathrm{min}^{-1}$.

The described experiments are part of the extensive research carried out at FPTM JEPU in Ústí nad Labem.

\section{Acknowledgements}

Above mentioned results were created by means of the project in J.E. Purkyně University in Usti nad Labem "Materials and Human Resources for Environment".

\section{REFERENCES}

1. Bauer R. Obrábění těžkoobrobitelných materiálů. 2008. [Available at: www http://www.mmspektrum.com/clanek/obrabeni-tezkoobrobitelnychmaterialu.html - cit. 2014-3-13].

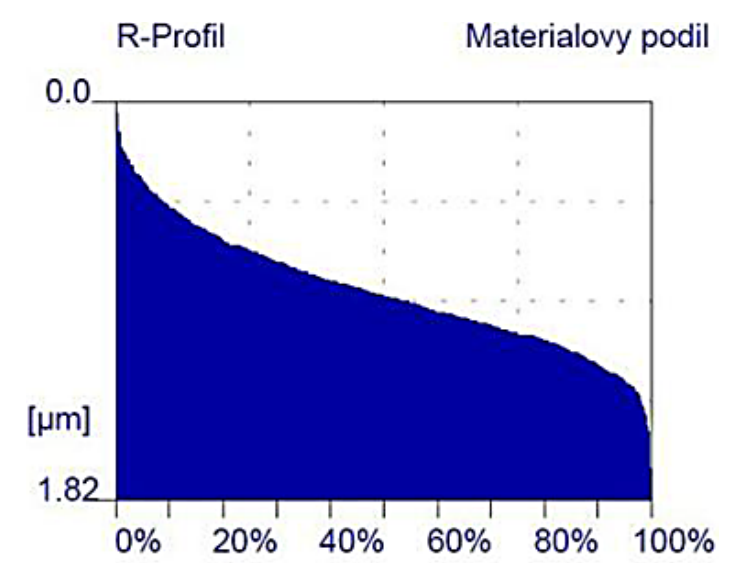

Fig. 24. Material ratio curve, grooving grinding, $\mathrm{v}_{\mathrm{c}}=40 \mathrm{~m} \cdot \mathrm{s}^{-1}, \mathrm{v}_{\mathrm{f}}=0.26 \mathrm{~mm} \cdot \mathrm{min}^{-1}$, sample 12

2. Byrne P. Turning milling and grinding processes. Arnold, London 1996.

3. INCONEL ${ }^{\circledR}$ alloy 718 (UNS N07718), 2007. [Available at: www http://www.hpalloy.com/alloys/ descriptions/INCONEL718.html - cit. 2014-3-13].

4. Novák M. Surface quality of hardened steels after grinding. Manufacturing Technology, 11(11), UJEP, Ústi nad Labem, 2011, 55-59.

5. Novak M. Surfaces with high precision of roughness after grinding. Manufacturing Technology, 12(13), 2012, 66-70.

6. Valíček J., Rusnák J., Müller M., Hrabě P., Kadnar M., Hloch S., Kušnerová M. Geometrické aspekty drsnosti povrchu klasických a netradičních technologií. Jemná Mechanika a Optika, 53(9), 2008, 249-253.

7. Kocman K. Optimalizace dokončovacích operaci výrobních procesů, Strojírenská Technologie, 17(3), 2012, 164-169.

8. Jusko O. Vývoj a inovace brousicích nástrojů. Strojírenská Technologie, 15(1), 2010, 17-22.

9. Novák M. Studium jakosti broušeného povrchu kalených ocelí, část I. - drsnost povrchu. Strojírenská Technologie, 16(6), 2011, 26-33.

10. Holešovský F., Novák M. Grinding and its influence to ground surface durability. Proceedings of International Conference on Advances in Materials and Processing Technologies, Paris. Amer INST Physics, Melville, NY, USA, 2010.

11. Kouřil K., Cep R., Janásek A., Kříž A., Stančeková D. Surface integrity at reaming operation by MT3 head. Manufacturing Technology, 14(2), 2014, 193-199.

\section{CZ.1.07/2.3.00/30.0028}

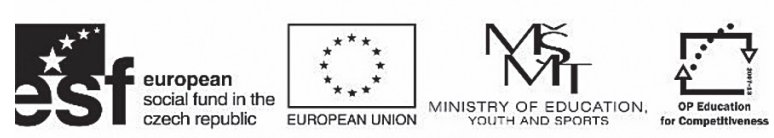

INVESTMENTS IN EDUCATION DEVELOPMENT 